\title{
Consolidation settlement calculation and examination of the foundation settlements with finite elements method, example of Batman city Gültepe bridge
}

\author{
Veysel Köylü ${ }^{1, *}$, Nuray Alpaslan ${ }^{1}$, Veysel Süleyman Yavuz ${ }^{2}$ \\ ${ }^{1}$ Batman University, Institute of Science,Department of Geology Engineering, Batman, vkoylu72@gmail.com, ORCID iD: 0000-0003-2154-4560 \\ ${ }^{1}$ Batman University, Department of Civil Engineering, Batman, nuray.alpaslan@batman.edu.tr, ORCID iD: 0000-0001-6430-1222 \\ ${ }^{2}$ Siirt University, Department of Civil Engineering, Siirt, vsyavuz@ siirt.edu.tr, ORCID iD: 0000-0002-5867-7677
}

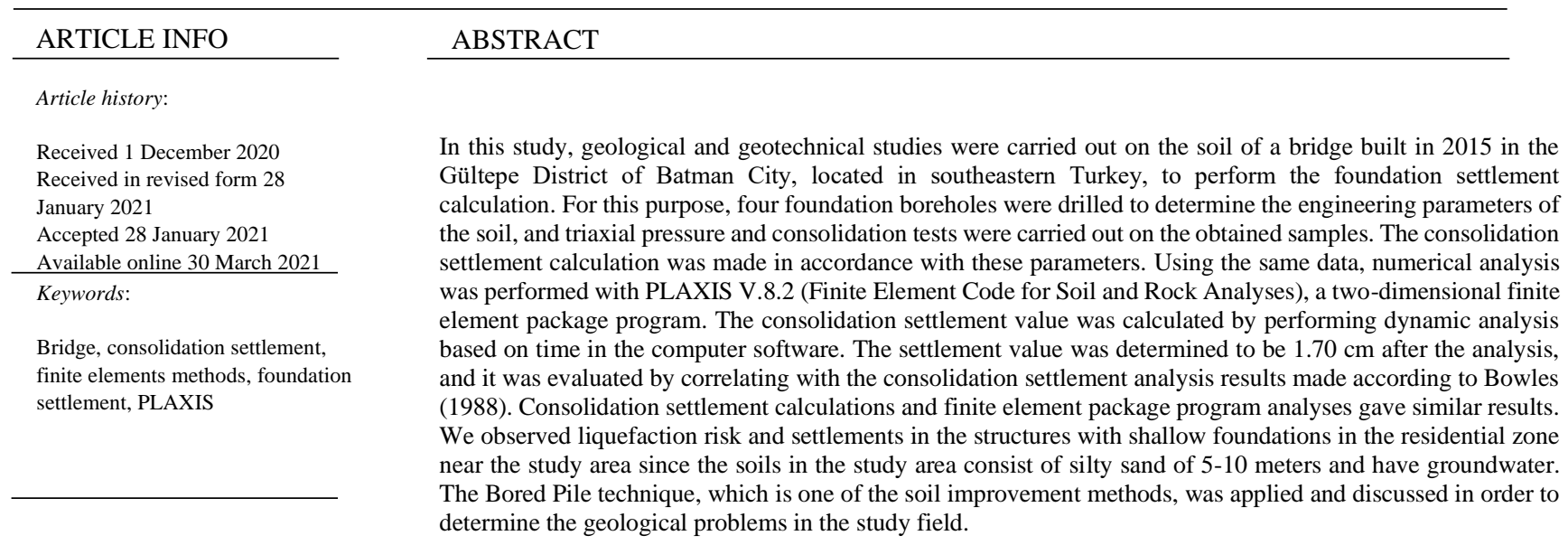

\footnotetext{
* Corresponding author

Veysel Köylü

$\bowtie$ vkoylu72@gmail.com
} 


\section{Introduction}

Soil has a heterogeneous structure; however, it can show changes on the meter or even centimeter scale. Soil is important in terms of being used as a building material and carrying the weights of engineering structures, such as buildings, bridges, roads and dams.

In designing and making stability calculations of big structures, such as bridges, it has become mandatory to determine the physical and mechanical properties of the foundation and the materials being used, as well as understanding the deformations developed against the forces on the charge [1]. The most prevalent factors in the settlement and collapse of bridges are as follows: the wear of the slope and the pier foundations, sliding of the slope and pier foundations, washing of the slope and pier foundations, deformation of the foundation, overloading the bridge, receiving more flood waters than expected, earthquakes, and poor calculation of the wind effects on suspension bridges. Therefore, it is quite important to consider settlements under the stress effect, which is transferred to the foundation soil in the design of engineering structures, such as bridge piers. Settlements formed beneath the structures, especially different settlements, may have negative effects on the structural behavior [2].

Soil is a non-homogeneous and anisotropic material. PLAXIS (static, dynamic stress analysis, and modeling program) is a finite element program that can be used for examining soil behavior. Many researchers conducted studies using the PLAXIS program. Brinkgreve et al. [3] used the two-dimensional PLAXIS 2D (Finite Element Code for Soil and Rock Analysis) software, which is based on the finite element method. Deformation analysis of different foundation types that settle on the soil can be performed with this program. Sert et al. [4] used the "Sensitivity Analysis and Parameter Change" option of the PLAXIS 2D software, which has been developed for analysis with the finite element method. In the models they obtained, they observed that the cohesion value in the clay had a greater impact on the results than the elasticity modulus of the shear resistance angle in the sand. There are many studies in the literature conducted with the PLAXIS program [5-7). Enkhtur et al. [8] made settlement calculations by using three different numerical analyses in their study on the numerical analysis of the shallow foundation settlement. Misir and Laman [9] examined the load bearing capacities of the circular foundations that settle on the granular filling layer built on remolded clayey soil with laboratory model experiments. They observed that the experimental data was in harmony by comparing the experimental data with an analytical relation.

\section{Geology}

Batman is located in the southeast of the Diyarbakır region between the Raman and Kıra Mountains (Figure 1). When the geological features of Batman province are examined, it is seen that ophiolitic rocks and sliced metamorphic rocks belonging to the Eurasian plate are located in the north of the Bitlis-Zagros Suture Zone (BZSZ) [10]. The oldest unit observed in Batman province and its surroundings is the Hoya Formation of the Midyat Group consisting of a sparsely argillaceous limestone level, limestone, dolomitic limestone, and dolomites of Lower Eocene-Lower Oligocene age; it is covered by the Germik Formation, consisting of locally dolomitic limestone and argillaceous limestone of Oligocene age, and it is followed by the Şelmo Formation of Middle-Upper Miocene age, consisting of conglomerate, sandstone, and mudstone. The Quaternary basalts forming Kira Mountain are on the Şelmo Formation; the Quaternary units consisting of alluviums are on the surface of the Batman River Valley and the surroundings of Batman (Figure 2). The Şelmo Formation is located in the city center of Batman and forms a large part of the study area [11]. This formation of Upper Miocene age consists of alternations of conglomerate, sandstone, siltstone, shale, and marl. The layer slopes of the Şelmo Formation in the region where sedimentation occurs in a fluvial and delta environment have directions and angles of short distances. This is due to the folds and strike-slip faults that occur as a result of tectonic events. Lithologically, it consists of alterations of pink, red, and brown coarse-grained, thick-bedded conglomerate with polygenic elements; sandstone with white and gray coarse-grained, thin, and indistinct bedding, with poorly cemented and polygenic elements; dirty yellow siltstone; white and light gray shale; light gray and yellowish marl and dark-greenish gray thin 
shale; and conglomerate containing yellowishgreenish gray sandstones [12-15].

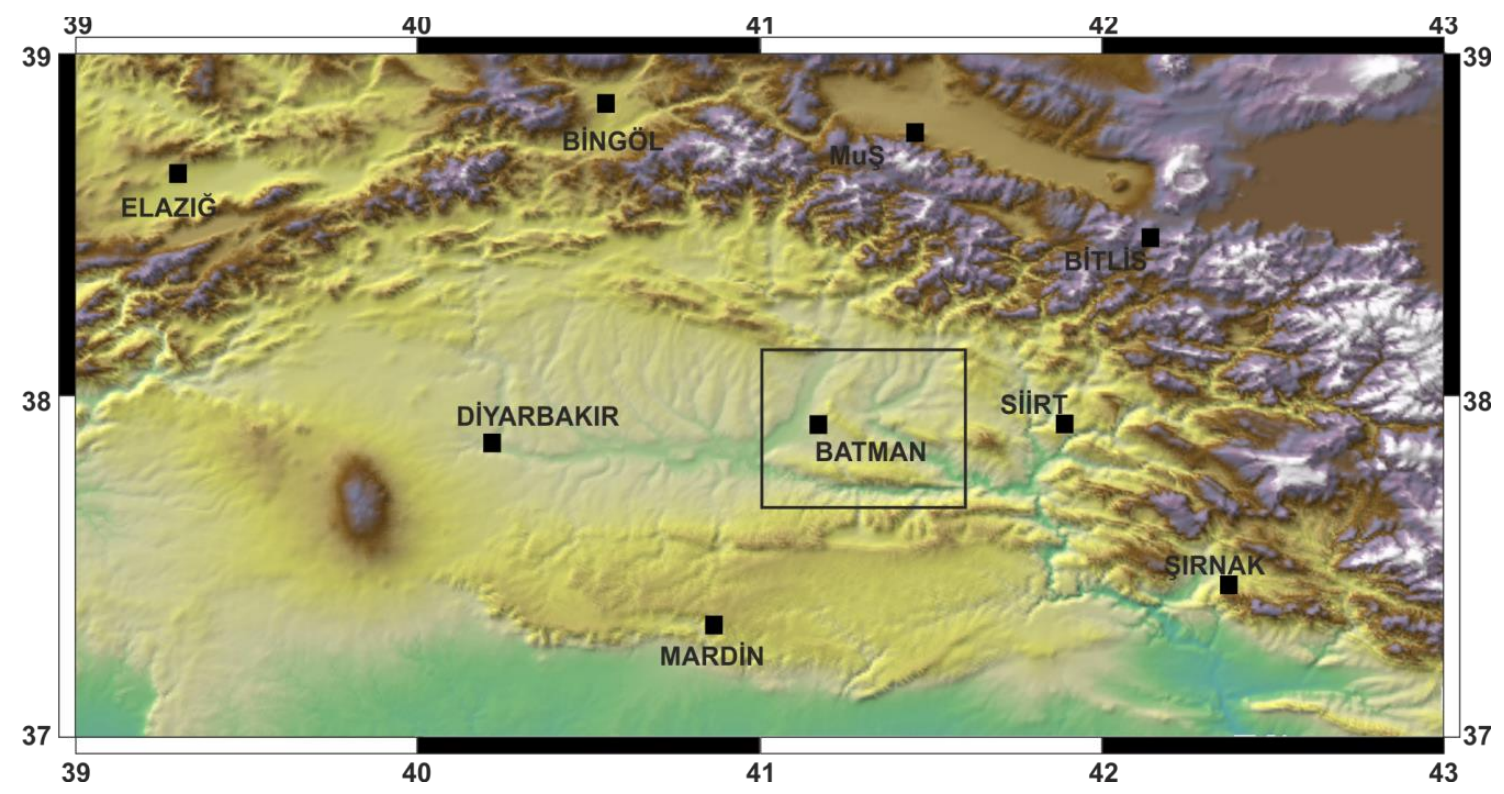

Figure 1. Survey site location

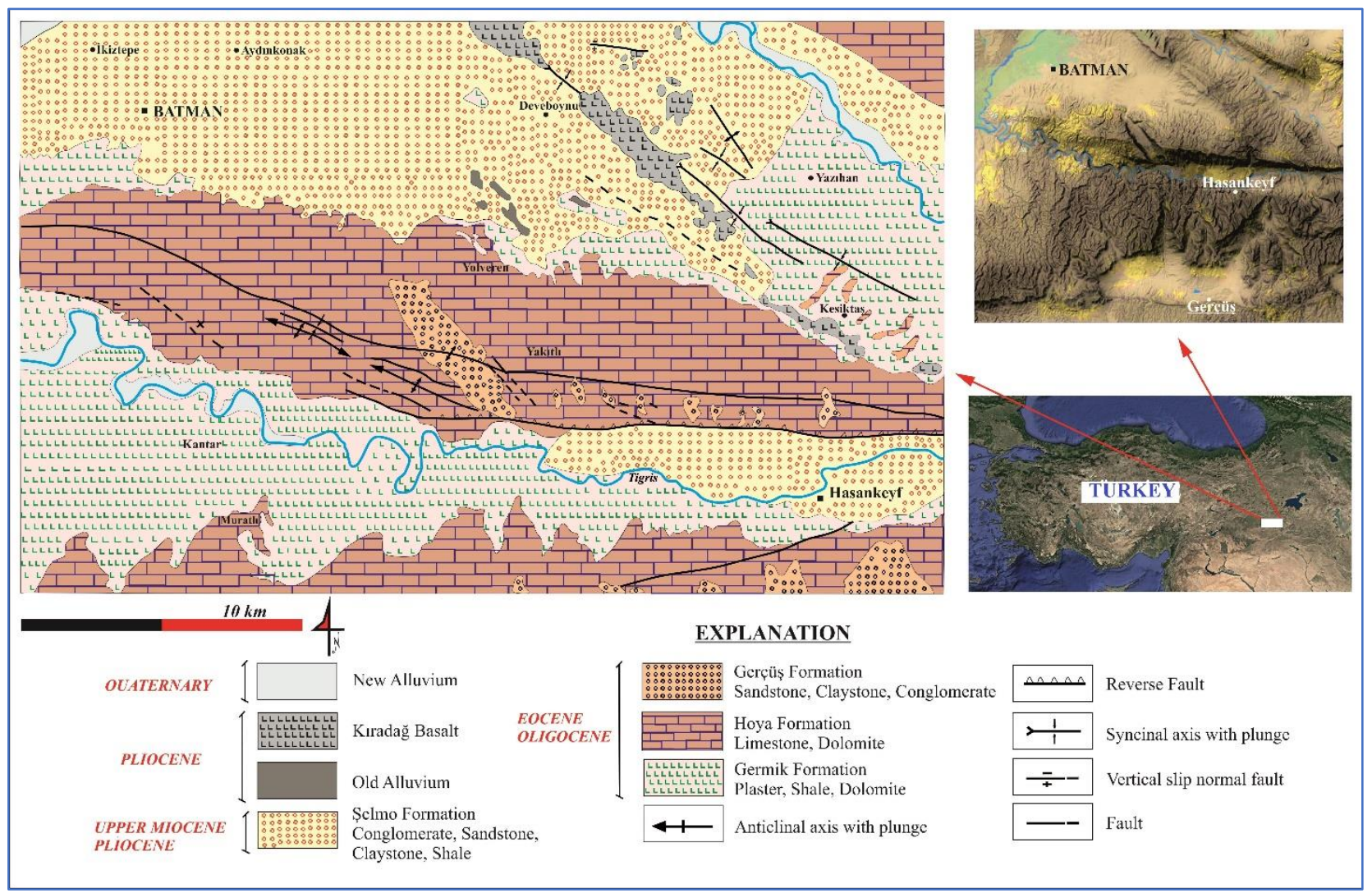

Figure 2. Geological map of Batman City (modified from The Institute of Mineral Research and Exploration (MTA) 1:500.000 scale geological map, [10] 


\section{Materials and methods}

\section{Materials}

In this study, four foundation boreholes $(\mathrm{BH})$ were drilled to a total depth of $80 \mathrm{~m}$ in order to determine the geological characteristics of the soil during the field surveys carried out at the Gültepe bridge, which is located in Batman city center (Figure 3).

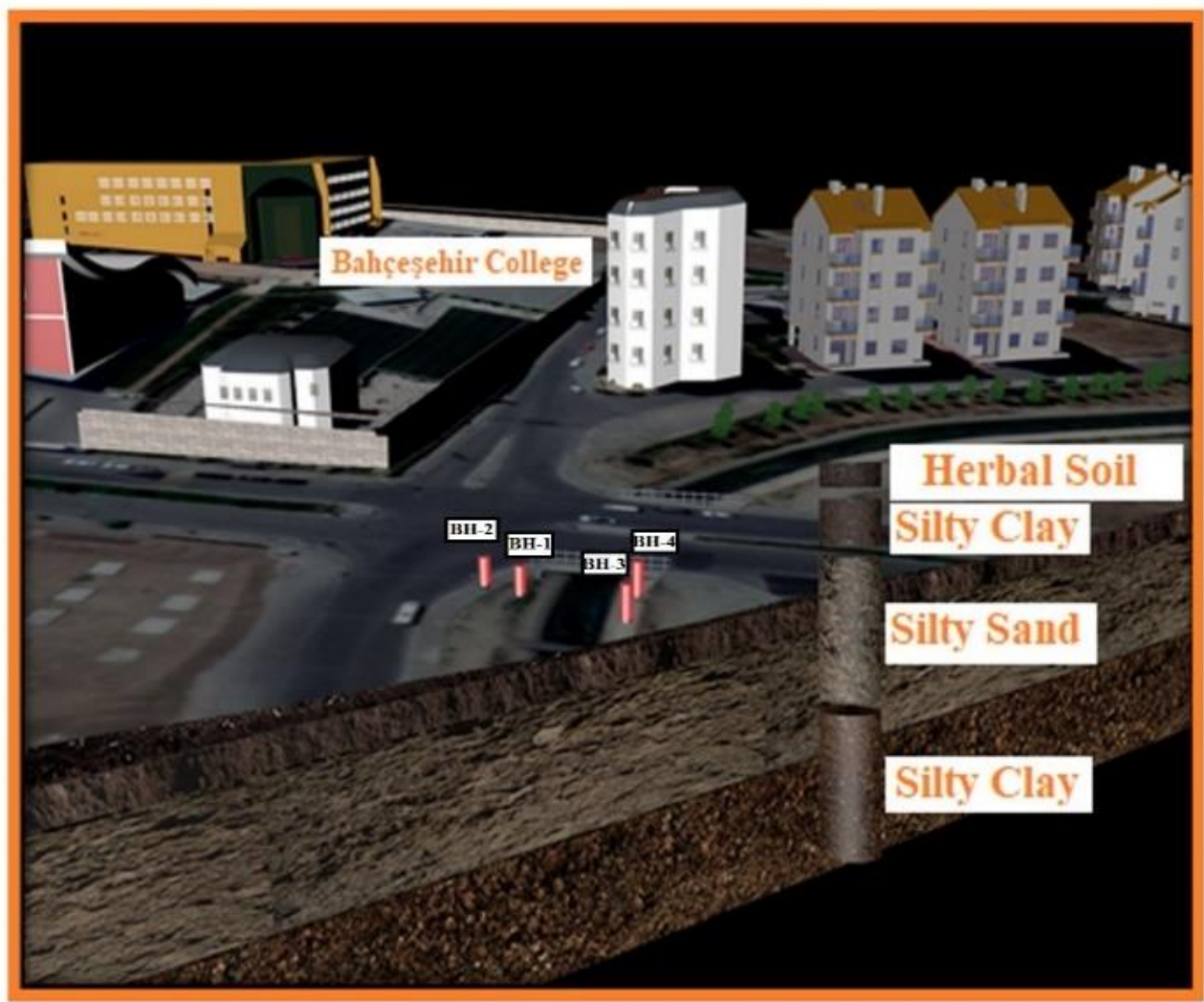

Figure 3. Three-dimensional view of the study area

The dominant lithology of the study area is weathered claystone, in which siltstone and sandstone levels take the form of lenses. Batman City is at a risky position for settlement because most of the settlements in the city have been built on alluvium. In the area where the city was founded and the basin behind it, most of the lithological structure is clayey and impermeable
(Figure 4a). In the drilled foundation boreholes, consolidated and brownish silty clay with low inorganic plasticity was observed between 0.5 and $5 \mathrm{~m}$. Silty sand was observed between 5-10 $\mathrm{m}$. Consolidated and brownish silty clay with low inorganic plasticity was observed between 10-20 m (Figure 4b). 


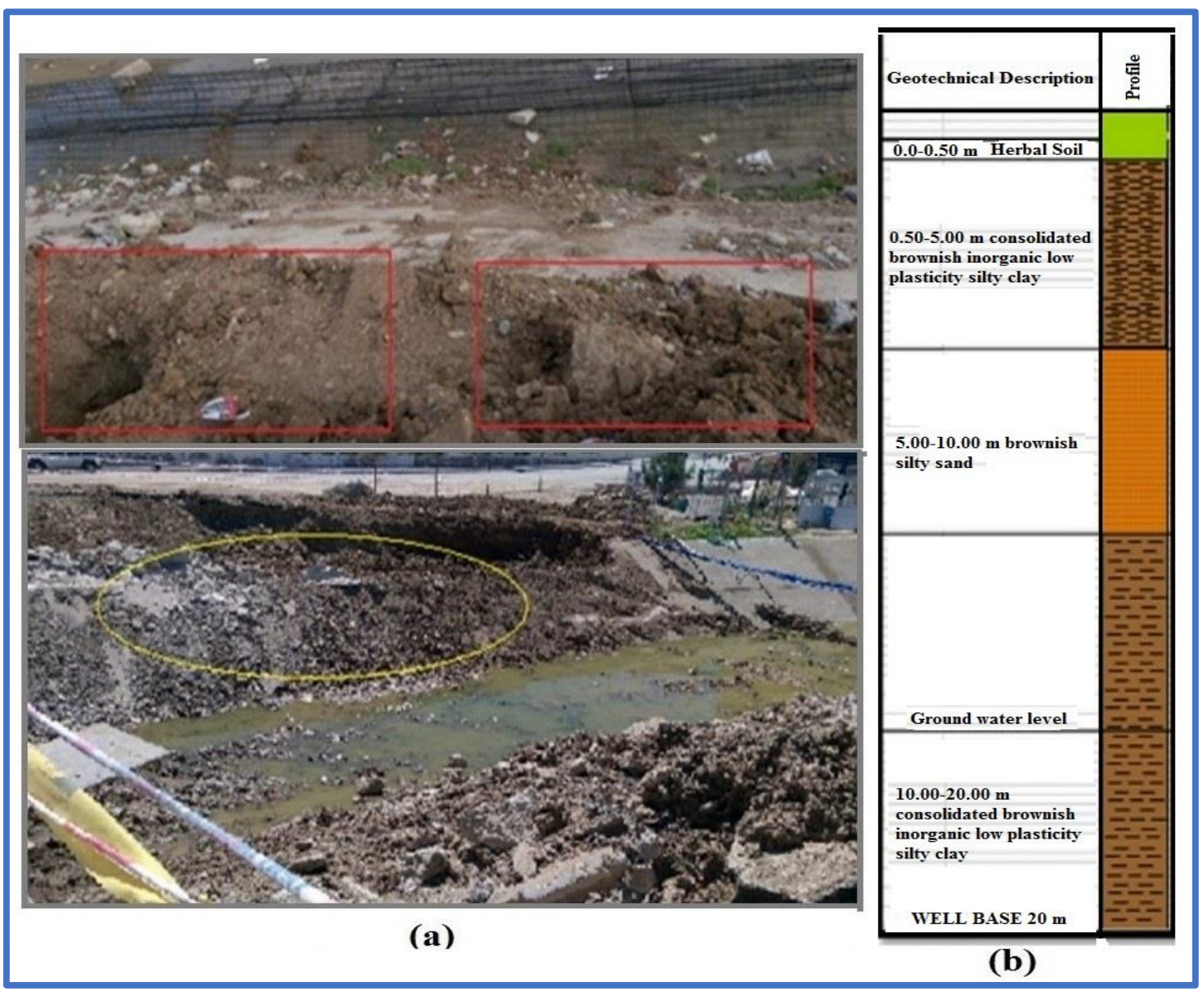

Figure 4. a) Soil appearance b) soil profile in the study area

In order to determine the carrying capacity of the units in the study area, calculations were made using the data obtained from a triaxial compression strength test carried out in the laboratory on the samples taken from the borehole. According to this, the ultimate bearing capacity for the shallow foundations is calculated using the Terzaghi and Peck [16] relation. Table 1 shows the results of the triaxial test. If we determine that the local sliding fracture will occur within the soil (in soft or close-to-soft, in loose or close-to-loose soil), maximum bearing capacity should be reduced. This reduction is made by scaling down the cohesion and internal friction angle by $2 / 3$. In order to achieve the best results for important areas and areas that have been exposed to natural disasters, cohesion (c) $\mathrm{kg} / \mathrm{cm}^{2}$ is multiplied by $2 / 3[16]$.

Table 1. Results of the triaxial compression test

\begin{tabular}{ccccc}
\hline $\begin{array}{c}\text { Borehole } \\
\mathbf{N} .\end{array}$ & $\begin{array}{c}\text { Depth } \\
(\mathbf{m e t e r s})\end{array}$ & $\begin{array}{c}\text { Cohesion } \\
(\mathbf{c}) \mathbf{~ k g} / \mathbf{c m}^{\mathbf{2}}\end{array}$ & $\begin{array}{c}\text { Internal Friction } \\
\text { Angle }\left(\boldsymbol{\phi}^{\mathbf{0}}\right)\end{array}$ & $\begin{array}{c}\text { Natural density } \\
\left(\mathbf{g} / \mathbf{c m}^{\mathbf{3}}\right)\end{array}$ \\
\hline BH-1 & 2.00 & 0.52 & 7 & 1.920 \\
BH-1 & 4.50 & 0.55 & 7 & 1.934 \\
BH-2 & 2.00 & 0.57 & 8 & 1.938 \\
BH-2 & 4.50 & 0.54 & 8 & 1.929 \\
BH-3 & 2.00 & 0.50 & 8 & 1.925 \\
BH-3 & 4.50 & 0.53 & 7 & 1.942 \\
BH-4 & 2.00 & 0.52 & 7 & 1.934 \\
BH-4 & 4.50 & 0.54 & 7 & 1.940 \\
\hline
\end{tabular}




\section{Methods}

In this study, the parameters required to perform the settlement calculation were determined as a result of the consolidation tests. The consolidation settlement calculation was made within the study using the equation Bowles [17] below.

$\mathrm{S}_{\mathrm{c}}=\mathrm{m}_{\mathrm{v}} \cdot \mathrm{H} \cdot \Delta \sigma^{\prime}$

In this equation, $S_{c}$ symbolizes the consolidation settlement amount of the stratum, $\Delta \sigma^{\prime}$ is the effective stress increase in the middle of the stratum due to loading, $\mathrm{mv}$ refers to the coefficient of volume compressibility, and $\mathrm{H}$ is the thickness of the clay stratum.

Analysis based on the stress distribution was conducted in the settlement calculation of the bridge piers in the study area. The vertical (V) and horizontal $(\mathrm{H})$ method was employed in the mathematical statement of the stress distribution [18] (Figure 5).

$\Delta \sigma=\frac{q_{n e t} * B * \mathrm{~L}}{((\mathrm{~B}+\mathrm{Z}) \times(\mathrm{L}+\mathrm{Z}))}$

In the equation, $q_{\text {net }}$ symbolizes net base pressure, $B$ is the foundation width, $L$ is the height, $Z$ is the thickness effect, and $\Delta \sigma$ represents the average stress increase in the soil stratum.

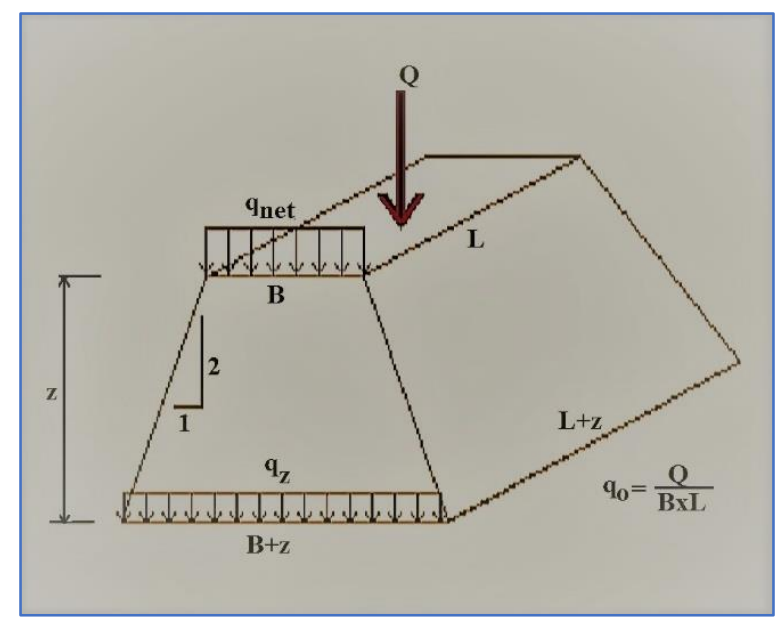

Figure 5. Vertical (V)-Horizontal (H) method [18]

\section{Findings}

\section{Results of the consolidation settlement calculation}

The settlement values for each drilling, which are calculated by using the data obtained from the boreholes in the study area, range between 12.32 and $7.090 \mathrm{~cm}$. Table 2 shows the settlement values calculated according to Bowles [17] for each borehole.

Table 2. Settlement values calculated according to Bowles [17] for each drilling

\begin{tabular}{cccc}
\hline Borehole & Depth $($ meters $)$ & Mv coefficient $\left(\mathbf{c m}^{\mathbf{2}} \mathbf{/ k g f}\right)$ & Settlement $(\mathbf{c m})$ \\
\hline BH-1 UD1 & 2.00 & 0.0211 & 11.93 \\
BH-1 UD2 & 4.50 & 0.0183 & 7.090 \\
BH-2 UD1 & 2.00 & 0.0202 & 11.37 \\
BH-2 UD2 & 4.50 & 0.0202 & 7.86 \\
BH-3 UD1 & 2.00 & 0.0215 & 12.13 \\
BH-3 UD2 & 4.50 & 0.0202 & 7.77 \\
BH-4 UD1 & 2.00 & 0.0219 & 12.32 \\
BH-4 UD2 & 4.50 & 0.0222 & 8.55 \\
\hline
\end{tabular}

\section{Calculation results according to the stress distribution}

The settlement values obtained from the study area are above the allowable values. No problems are expected in terms of excavation safety at this foundation depth. The soil, which consists of low plasticity clay (CL) and silty sand (SM) in accordance with the unified soil classification system (USCS), is not expected to cause a total and different settlement at a rate that can damage 
the above-mentioned engineering structure. In the study area, settlement between 11.93 and $12.32 \mathrm{~cm}$ is observed at $2 \mathrm{~m}$ and between 7.09 and $8.55 \mathrm{~cm}$ at $4.5 \mathrm{~m}$.

\section{Bridge Pier 1- Settlement at $\mathbf{2} \mathbf{~ m}$}

$q_{\text {excavation }}=\mathrm{Df}^{*} \gamma=2^{*} 19.20=38.4$

$q_{\text {net }}=q_{\text {pier }}-q_{\text {excavation }}=130-38.4=$

$91.6 \mathrm{kpa}$

$\mathrm{Df}=2 \mathrm{~m}$, therefore, $\mathrm{z}$ is taken as 1.5 since the clay stratum thickness will be $5 \mathrm{~m}$ and the thickness effect will be $3 \mathrm{~m}$.

$\Delta \sigma=\frac{q_{n e t}{ }^{*} \mathrm{~B}^{*} \mathrm{~L}}{((\mathrm{~B}+\mathrm{Z}) \times(\mathrm{L}+\mathrm{Z}))}=\frac{91.6 \times 2 \times 7.40}{(2+1.5) \times(7.40+1.5)}=$ $43.52 \mathrm{kPa}=0.435 \mathrm{kgf} / \mathrm{cm}^{2}$

$\mathrm{S}=\mathrm{M}_{v} \times \mathrm{H} \times \Delta \sigma=0.0211 \times 1300 \times 0.435=$ $11.93 \mathrm{~cm}$

\section{Bride Pier 1- Settlement at $4.5 \mathrm{~m}$}

$q_{\text {excavation }}=\mathrm{Df}^{*} \gamma=4.5^{*} 19.34=87.03$

$q_{\text {net }}=q_{\text {pier }}-q_{\text {excavation }}=130-87.03=$

$42.97 \mathrm{kpa}$

$\mathrm{Df}=4.5 \mathrm{~m}$, therefore, $\mathrm{z}$ is taken as 0.25 since the clay stratum thickness will be $5 \mathrm{~m}$ and the thickness effect will be $0.50 \mathrm{~m}$.

$\Delta \sigma=\frac{q_{n e t}{ }^{*} \mathrm{~B}^{*} \mathrm{~L}}{((\mathrm{~B}+\mathrm{Z}) \times(\mathrm{L}+\mathrm{Z}))}=\frac{42.97 \times 2 \times 7.40}{(2+0.25) \times(7.40+0.25)}=$ $36.34 \mathrm{kPa}=0.369 \mathrm{kgf} / \mathrm{cm}^{2}$

$\mathrm{S}=\mathrm{M}_{v} \times \mathrm{H} \times \Delta \sigma=0.1083 \times 1050 \times$

$0.369=7.090 \mathrm{~cm}$

Bridge Pier 2- Settlement at 2 m

$q_{k a z l}=\mathrm{Df}^{*} \gamma=2 * 19.38=38.76$

$q_{\text {net }}=q_{\text {pier }}-q_{\text {excavation }}=130-38.76=$

$91.24 \mathrm{kpa}$
$\mathrm{Df}=2 \mathrm{~m}$, therefore, $\mathrm{z}$ is taken as 1.5 since the clay stratum thickness will be $5 \mathrm{~m}$ and the thickness effect will be $3 \mathrm{~m}$.

$\Delta \sigma=\frac{q_{n e t}{ }^{*} \mathrm{~B}^{*} \mathrm{~L}}{((\mathrm{~B}+\mathrm{Z}) \times(\mathrm{L}+\mathrm{Z}))}=\frac{91.24 \times 2 \times 7.40}{(2+1.5) \times(7.40+1.5)}=$ $43.34 \mathrm{kPa}=0.433 \mathrm{kgf} / \mathrm{cm}^{2}$

$\mathrm{S}=\mathrm{M}_{v} \times \mathrm{H} \times \Delta \sigma=0.0202 \times 1300 \times$

$0.433=11.37 \mathrm{~cm}$

\section{Bridge Pier 2- Settlement at $4.5 \mathrm{~m}$}

$q_{\text {excavation }}=\mathrm{Df}^{*} \gamma=4.5 * 19.29=86.80$

$q_{\text {net }}=q_{\text {pier }}-q_{\text {excavation }}=130-86.80=$ $43.2 \mathrm{kpa}$

$\mathrm{Df}=4.5 \mathrm{~m}$, therefore, $\mathrm{z}$ is taken as 0.25 since the clay stratum thickness will be $5 \mathrm{~m}$ and the thickness effect will be $0.50 \mathrm{~m}$.

$\Delta \sigma=\frac{q_{n e t}{ }^{*} \mathrm{~B}^{*} \mathrm{~L}}{((\mathrm{~B}+\mathrm{Z}) \times(\mathrm{L}+\mathrm{Z}))}=\frac{43.2 \times 2 \times 7.40}{(2+0.25) \times(7.40+0.25)}=$

$37.14 \mathrm{kPa}=0.371 \mathrm{kgf} / \mathrm{cm}^{2}$

$\mathrm{S}=\mathrm{M}_{v} \times \mathrm{H} \times \Delta \sigma=0.0202 \times 1050 \times$

$0.371=7.86 \mathrm{~cm}$

\section{Bridge Pier 3- Settlement at 2 m}

$q_{\text {excavation }}=\mathrm{Df}^{*} \gamma=2 * 19.25=38.5$

$q_{\text {net }}=q_{\text {pier }}-q_{\text {excavation }}=130-38.5=$

$91.5 \mathrm{kpa}$

$\mathrm{Df}=2 \mathrm{~m}$, therefore, $\mathrm{z}$ is taken as 1.5 since the clay stratum thickness will be $5 \mathrm{~m}$ and the thickness effect will be $3 \mathrm{~m}$.

$$
\begin{gathered}
\Delta \sigma=\frac{q_{\text {net }}{ }^{*} \mathrm{~B}^{*} \mathrm{~L}}{((\mathrm{~B}+\mathrm{Z}) \times(\mathrm{L}+\mathrm{Z}))}=\frac{91.5 \times 2 \times 7.40}{(2+1.5) \times(7.40+1.5)}= \\
43.47 \mathrm{kPa}=0.434 \mathrm{kgf} / \mathrm{cm}^{2}
\end{gathered}
$$

$\mathrm{S}=\mathrm{M}_{v} \times \mathrm{H} \times \Delta \sigma=0.0215 \times 1300 \times$

$0.434=12.13 \mathrm{~cm}$ 


\section{Bridge Pier 3- Settlement at $4.5 \mathrm{~m}$}

$q_{\text {excavation }}=\mathrm{Df}^{*} \gamma=4.5 * 19.42=87.39$

$q_{\text {net }}=q_{\text {pier }}-q_{\text {excavation }}=130-87.39=$

$\mathrm{Df}=4.5 \mathrm{~m}$, therefore, $\mathrm{z}$ is taken as 0.25 since the clay stratum thickness will be $5 \mathrm{~m}$ and the thickness effect will be $0.50 \mathrm{~m}$.

$\Delta \sigma=\frac{q_{n e t}{ }^{*} \mathrm{~B}^{*} \mathrm{~L}}{((\mathrm{~B}+\mathrm{Z}) \times(\mathrm{L}+\mathrm{Z}))}=\frac{42.61 \times 2 \times 7.40}{(2+0.25) \times(7.40+0.25)}=$

$36.63 \mathrm{kPa}=0.366 \mathrm{kgf} / \mathrm{cm}^{2}$

$\mathrm{S}=\mathrm{M}_{v} \times \mathrm{H} \times \Delta \sigma=0.0202 \times 1050 \times$

$0.366=7.77 \mathrm{~cm}$

Bridge Pier 4- Settlement at 2 m

$q_{\text {excavation }}=\mathrm{Df}^{*} \gamma=2 * 19.34=38.68$

$q_{\text {net }}=q_{\text {pier }}-q_{\text {excavation }}=130-38.68=$

$91.32 \mathrm{kpa}$

$\mathrm{Df}=2 \mathrm{~m}$, therefore, $\mathrm{z}$ is taken as 1.5 since the clay stratum thickness will be $5 \mathrm{~m}$ and the thickness effect will be $3 \mathrm{~m}$.

$\Delta \sigma=\frac{q_{n e t}{ }^{*} \mathrm{~B}^{*} \mathrm{~L}}{((\mathrm{~B}+\mathrm{Z}) \times(\mathrm{L}+\mathrm{Z}))}=\frac{91.32 \times 2 \times 7.40}{(2+1.5) \times(7.40+1.5)}=$ $43.38 \mathrm{kPa}=0.433 \mathrm{kgf} / \mathrm{cm}$

$$
\begin{aligned}
& \mathrm{S}=\mathrm{M}_{v} \times \mathrm{H} \times \Delta \sigma=0.0219 \times 1300 \times \\
& 0.433=12.32 \mathrm{~cm}
\end{aligned}
$$

\section{Bridge Pier 4- Settlement at $4.5 \mathrm{~m}$}

$q_{\text {excavation }}=\mathrm{Df}^{*} \gamma=4.5 * 19.40=87.30$

$q_{\text {net }}=q_{\text {pier }}-q_{\text {excavation }}=130-87.30=$ $42.7 \mathrm{kpa}$

$\mathrm{Df}=4.5 \mathrm{~m}$, therefore, $\mathrm{z}$ is taken as 0.25 since the clay stratum thickness will be $5 \mathrm{~m}$ and the thickness effect will be $0.50 \mathrm{~m}$.

$\Delta \sigma=\frac{q_{n e t}{ }^{*} \mathrm{~B}^{*} \mathrm{~L}}{((\mathrm{~B}+\mathrm{Z}) \times(\mathrm{L}+\mathrm{Z}))}=\frac{42.7 \times 2 \times 7.40}{(2+0.25) \times(7.40+0.25)}=$

$36.71 \mathrm{kPa}=0.367 \mathrm{kgf} / \mathrm{cm}^{2}$

$\mathrm{S}=\mathrm{M}_{v} \times \mathrm{H} \times \Delta \sigma=0.0222 \times 1050 \times$

$0.367=8.55 \mathrm{~cm}$

\section{The models obtained with PLAXIS}

PLAXIS V.8.2 (Finite Element Code for Soil and Rock Analyses) [19] is computer software that has been designed to analyze and determine problems in Geotechnical Engineering, such as deformation and stability, with the finite element method, and enables the asymmetric modeling of plane deformation and soil rock behavior. Tables 3 and 4 show the characteristics of soil, bored pile, and bridge parameters for the model used.

Table 3. The characteristics of soil parameters

\section{Analysis parameters of the clayey soil}

\begin{tabular}{ccc}
\hline Internal friction angle & $\left(\phi^{0}\right)$ & 7 \\
Soil unit weight & $\gamma\left(\mathrm{kN} / \mathrm{m}^{3}\right)$ & 19 \\
Cohesion & $\mathrm{c}\left(\mathrm{kN} / \mathrm{m}^{2}\right)$ & 50 \\
Poisson ratio & $v$ & 0.30 \\
Young's modulus & $E\left(\mathrm{~kg} / \mathrm{cm}^{2}\right)$ & 1323.5 \\
\multicolumn{1}{c}{ Analysis parameters of silty sand soil } & \\
Internal friction angle & $\left(\phi^{\circ}\right)$ & 32 \\
Soil unit weight & $\gamma\left(\mathrm{kN} / \mathrm{m}^{3}\right)$ & 19 \\
Cohesion & $\mathrm{c}\left(\mathrm{kN} / \mathrm{m}^{2}\right)$ & 5 \\
Poisson ratio & $v$ & 0.43 \\
Young's modulus & $E\left(\mathrm{~kg} / \mathrm{cm}^{2}\right)$ & 2387.5 \\
\hline
\end{tabular}


Table 4. The characteristics of piling, bridge, and load parameters

\begin{tabular}{ccc}
\hline \multicolumn{3}{c}{ Bored pile parameters } \\
\hline Material type & Elastic \\
EA (Axial stiffness) & $4.58 \times 10^{6} \mathrm{kN} / \mathrm{m}$ \\
EI (Bending stiffness) & Bridge parameters & $83480 \mathrm{kNm} / \mathrm{m}$ \\
Material type & & Elastic \\
EA (Axial stiffness) & $1.91 \times 10^{6} \mathrm{kN} / \mathrm{m}$ \\
EI (Bending stiffness) & Load & $34780 \mathrm{kNm} / \mathrm{m}$ \\
Vertical (y) & & $100 \mathrm{kN} / \mathrm{m}^{2}$ \\
\hline
\end{tabular}

Since PLAXIS is two-dimensional the bridge was modeled in the depth and horizontal (x) with the perspective from the irrigation channel beneath it (Figure 6). The bridge piers in the model gathered at one point as one on the right and one on the left. Bridge loads were formed according to the static loads and drainage conditions.
The model was created by using three strata at different depths. The geometry of the model includes: foundation at 0-2 $\mathrm{m}$, silty clay at $0-5 \mathrm{~m}$, silty sand at 5-10 m, silty clay at $10-20 \mathrm{~m}$, and bored pile at 0-18 $\mathrm{m}$ for the analysis (Figure 6). Figure 7 shows the finite element network.

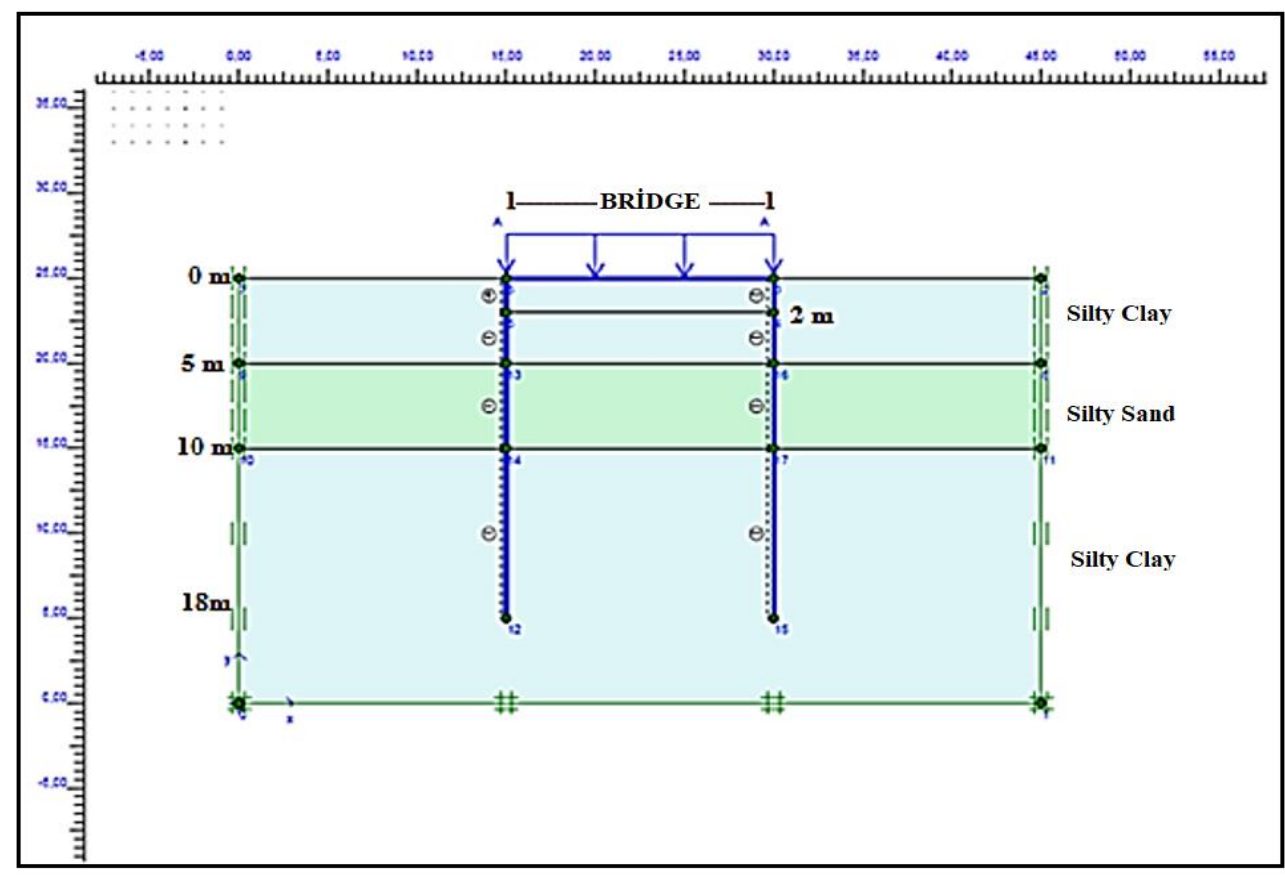

Figure 6. Model geometry 


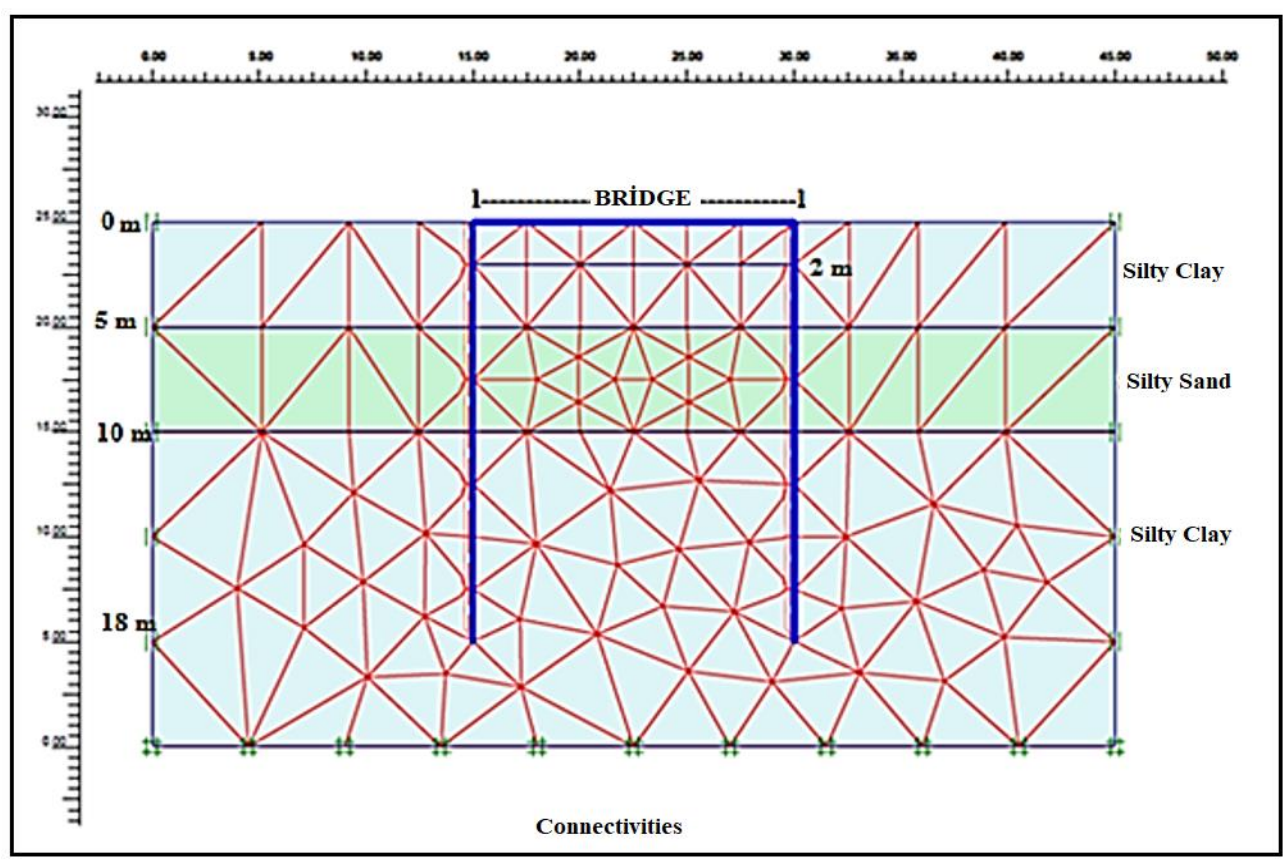

Figure 7. Finite element network

Pore water pressure increases linearly starting at the groundwater level. The capillary zone is under negative stress due to the tensile stress of water. In the drillings carried out in the survey area, the groundwater level was at $15 \mathrm{~m}$. The groundwater level should be determined before carrying out the analysis in the calculation section of PLAXIS. Therefore, the active pore water pressure stemming from the weight of the soil and its position 15 meters beneath the groundwater level were created in Figure 8, before building the bridge and bored piles.

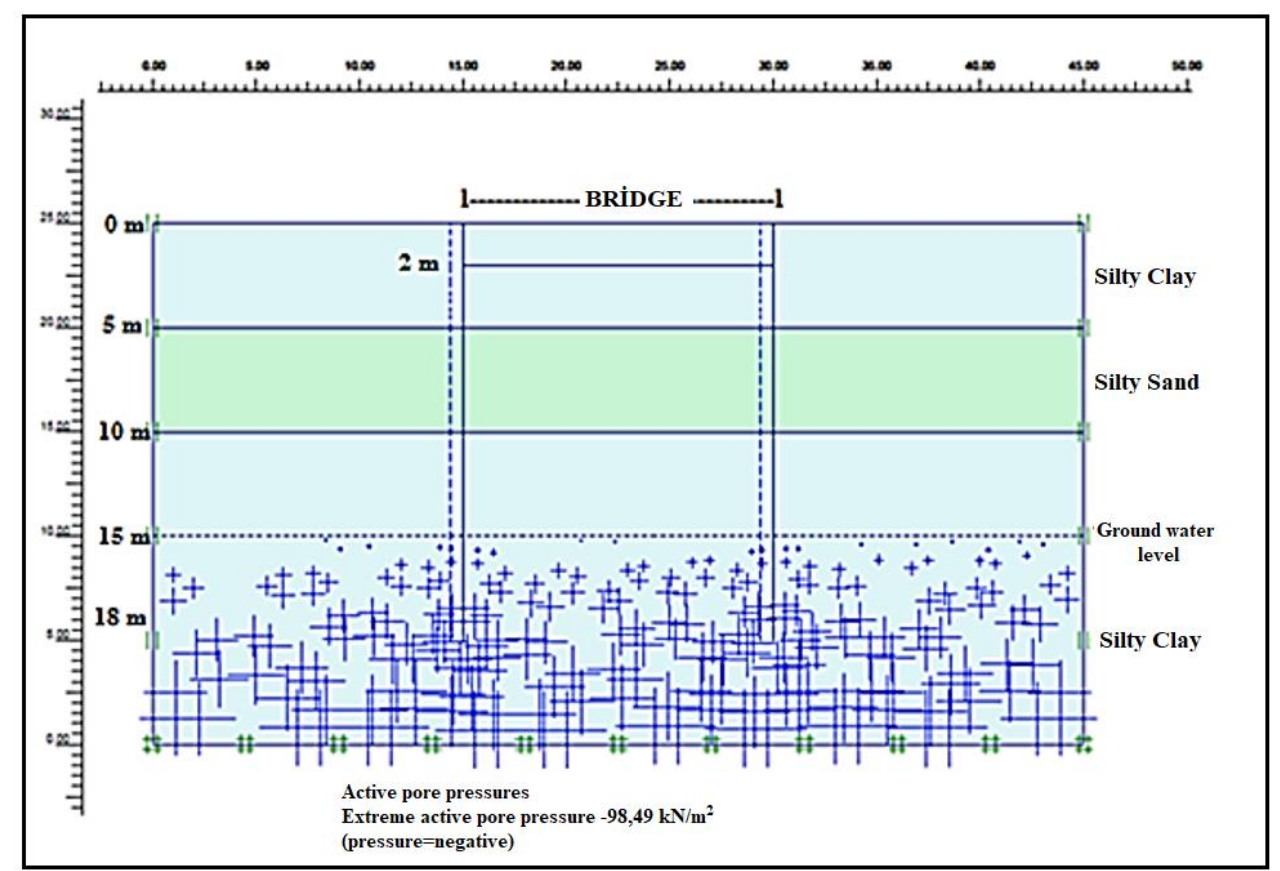

Figure 8. Groundwater level 
Figures 9 and 10 show the displacement vectors obtained with the analysis result conducted in PLAXIS. These are the respective total and vertical displacement vectors, and displacements are seen to intensify in the silty sand soil in between.

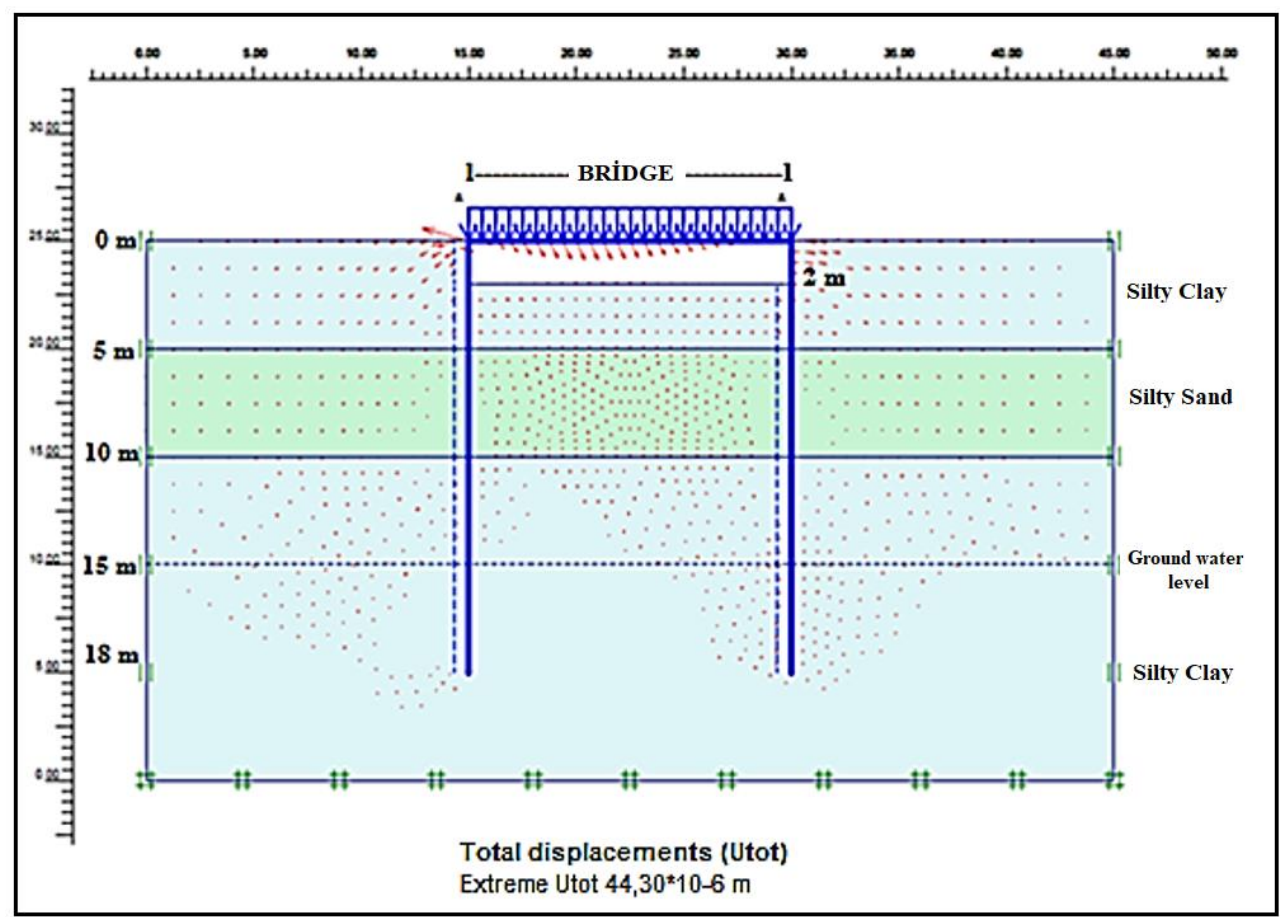

Figure 9. Total displacement vectors

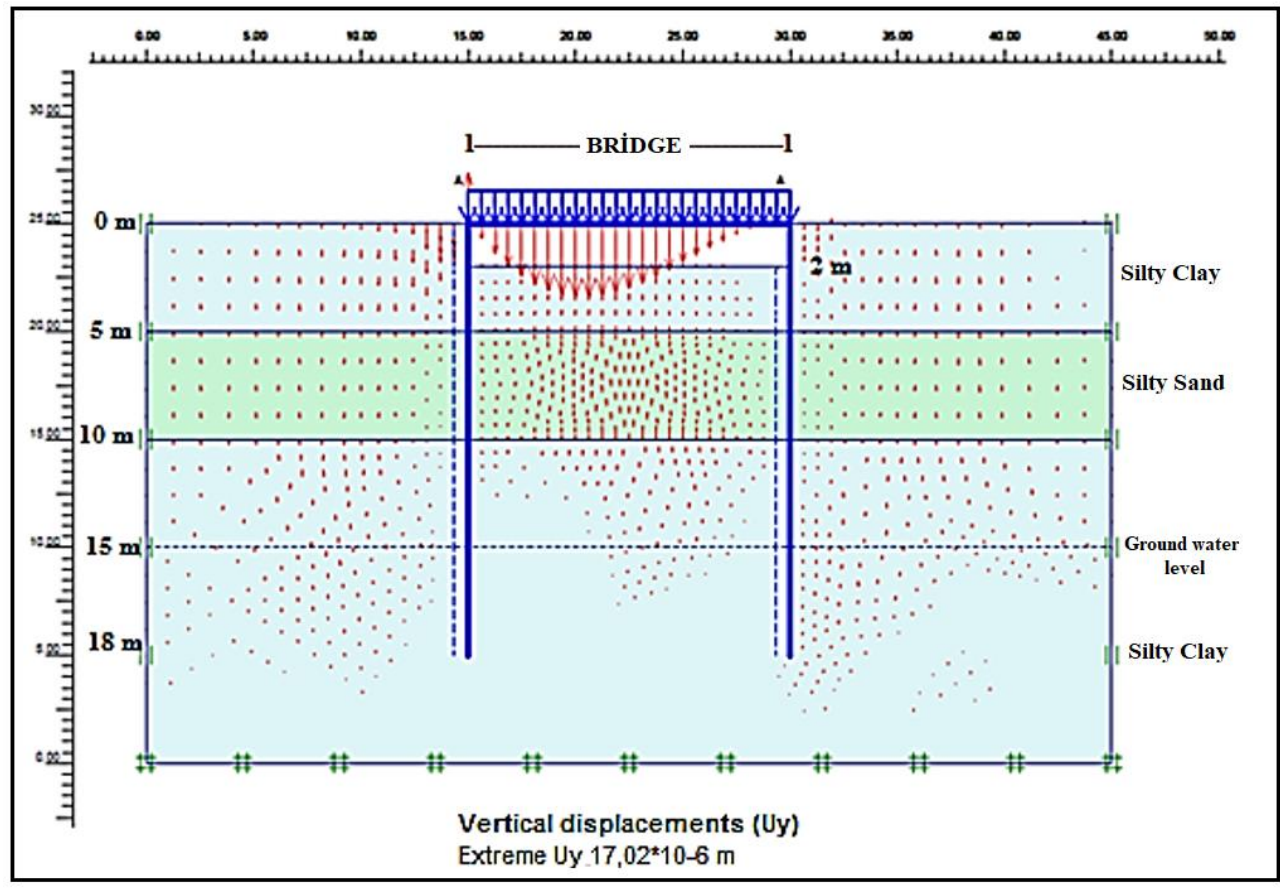

Figure 10. Vertical displacement vectors 
The displacement values obtained with PLAXIS are as follows: total displacement of $44.30 \times 10^{-6}$ $\mathrm{m}$ and vertical displacement if $17.02 \times 10^{-6} \mathrm{~m}$, and these values are negligible.

Effective stresses control the important engineering behaviors, such as compaction, shape deformation, and resistance to shear stresses of the soil. In other words, effective stress is affected by the pore water pressure beneath the groundwater stratum and the total vertical pressures. In the effective stresses in Figure 11, a concentration can be seen around the bored piles on the silty clay soil in the lowest stratum, and this concentration can be said to affect the silty sand soil in the upper stratum.

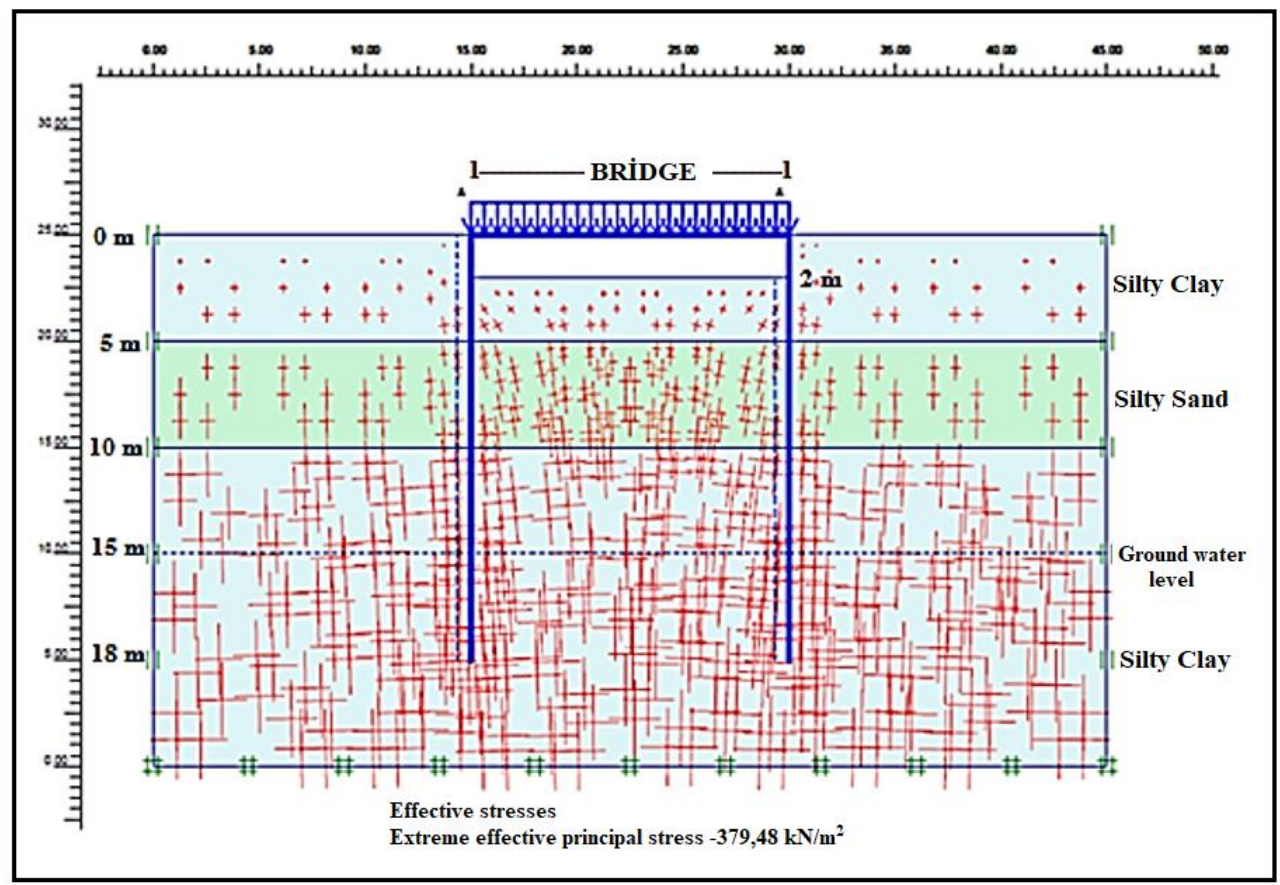

Figure 11. Effective stresses

In the bored pile technique applied in the study area, piles, bridge foundations, bridges, and bridge loads are defined in the program, and active pore water pressures occurring on the soil are also shown in Figure 12. Accordingly, it can be said that the pore water pressures from the lowest stratum of the silty clay soil to the silty sand soil with a height of $5 \mathrm{~m}$ between, and there may be a risk of liquefaction in this area. During liquefaction, the pore water pressure increases between the grains that form the soil. As soon as the pore water pressure is equal to the total stress, the friction force between the grains reaches zero. Settlement problems occur in the foundation soil. 


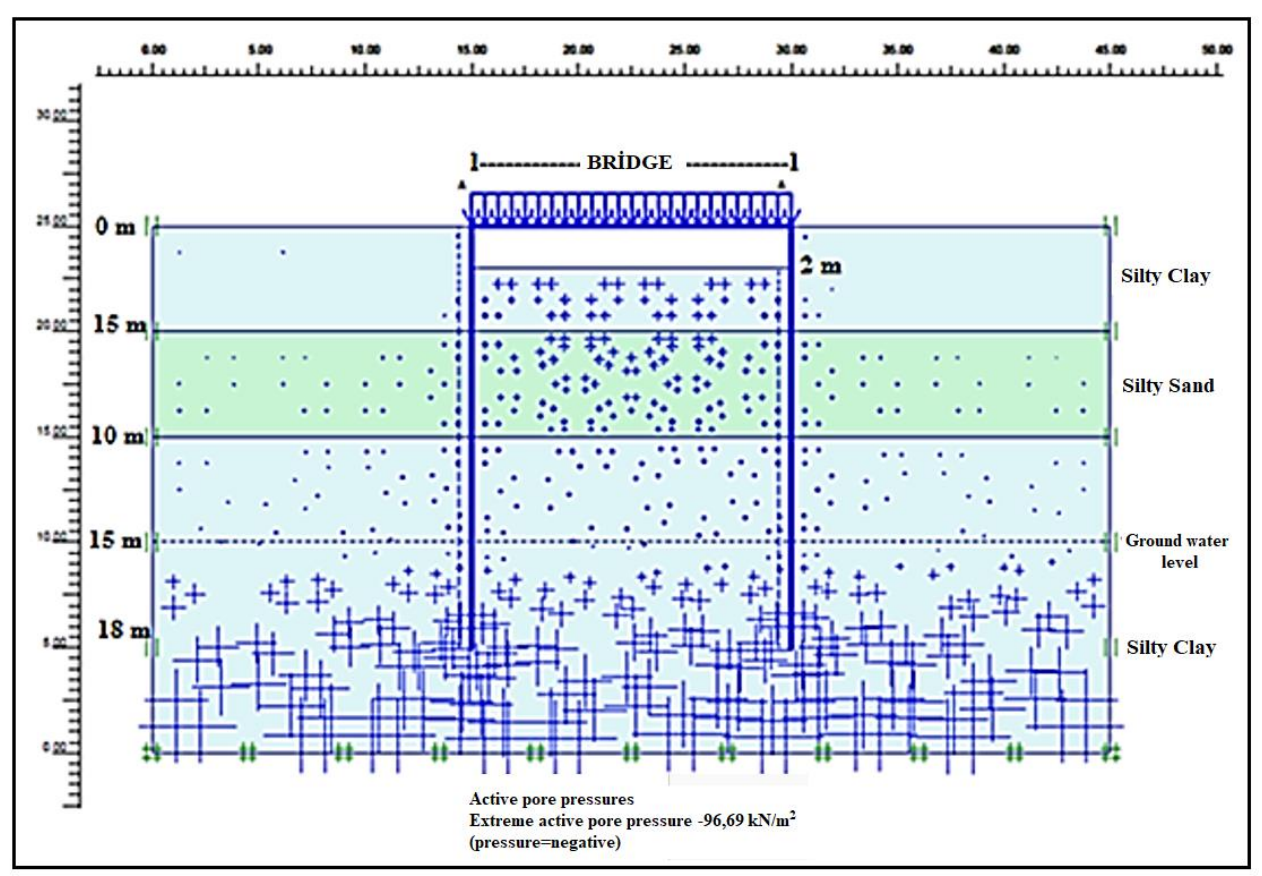

Figure 12. Active pore water pressure

Considering that the soil is mainly clay in the study area, it is thought that consolidation settlement analysis is necessary. The settlement value was found to be $1.70 \mathrm{~cm}$ in the consolidation settlement analysis conducted with the temporal dynamic analysis of PLAXIS. In accordance with the analysis results, we conclude that the structure does not have an issue in terms of settlement. The low pebbly clay level in the study area is the unit where the foundation will settle, and soil improvement methods are required for construction. Therefore, bored pile technique was applied in the area as a soil improvement method. Figure 13 shows the threedimensional view of the bored pile technique applied in the area and each Bored Pile has an 80 $\mathrm{cm}$ diameter and is $18 \mathrm{~m}$ in length. Excavation was primarily made at the building site in the study area, followed by the manufacturing of a total of 40 bored piles, each of which are $80 \mathrm{~cm}$ in diameter, $1800 \mathrm{~cm}$ in length, and $150 \mathrm{~cm}$ apart. Then, the building was completed after making the column footing, calculating the vehicle loads, and the design process. 


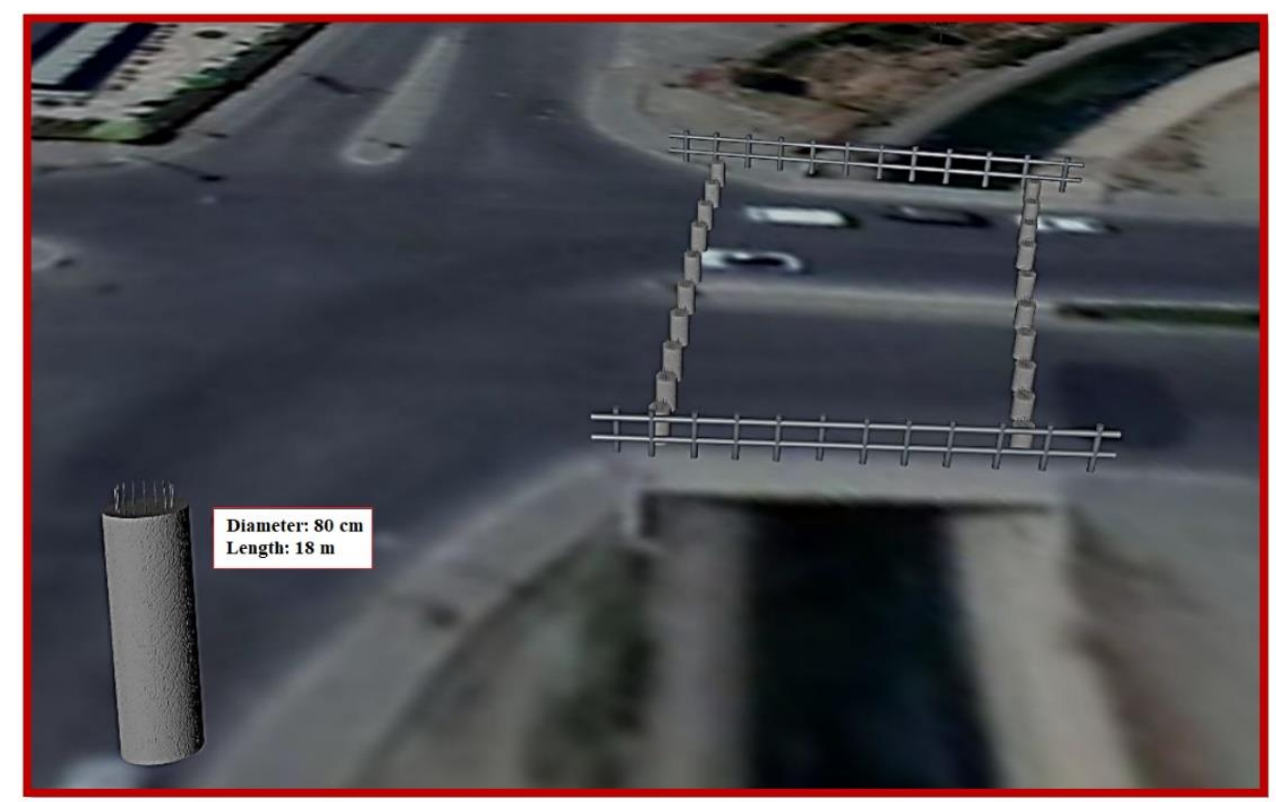

Figure 13. Three-dimensional view of the bored pile application in the study area

\section{Conclusions}

Four foundation boreholes were drilled in order to determine the lithological and geological conditions of the soil, as well as the engineering parameters in the Batman city Gültepe location. During the drilling of the borehole, assessments were made with the upper and lower depths of the soil strata, sampled levels, groundwater level, and all other observations. Settlements and stresses occurring at the base of the bridge legs in the study area were determined using the PLAXIS computer software, and the models created were correlated according to the geological data. Since the groundwater level is deeper than the foundation level, its impact on our foundation is not considered. However, the groundwater poses a risk to the liquidity of the sandy soil unit between 5 and $10 \mathrm{~m}$ depth. A settlement analysis was also conducted with PLAXIS, and this settlement value almost supported the consolidation settlement results. In the settlement calculation of the structure to be built (according to USCS class), the soil consisting of low plasticity clay (CL) and silty sand (SM) is not expected to cause a total and different settlement at a rate that can damage the above-mentioned engineering structure. Due to the fact that the soil consists of 5-10 m of silty sand in the study area, there is a risk of liquefaction due to the presence of groundwater, and settlements are observed in structures with shallow foundations in residential areas close to the study area, bored piling, which is one of the soil improvement techniques, was applied for the proposed bridge.

\section{References}

1. B. Canik, Engineering Geology Lecture Notes, Ankara: Ankara University Faculty of Science Department of Geology Engineering, 1997.

2. M. Yıldırım and E. Gökaşan, Geology Information for Engineerings, Expanded 2nd Edition, İstanbul: Yıldız Teknik University Publishing, 2013.

3. R. B. J. Brinkgreve, W. Broere, and D. Waterman, PLAXIS Finite Element Code for Soil and Rock Analysis. 2d -Version 8.6., The Netherlands: Delft University of Technology \& Plaxis, 2004.

4. S. Sert, A. Önalp and E. Arel, "Effect of Change in Soil Properties on Results in Numerical Analysis", Thirteenth National Congress of Soil Mechanics and Foundation Engineering, İstanbul Kültür University, İstanbul, 471-482, (2010).

5. E. Subaşı, B. İkizler, G. Demir, Z. Angın and A. Kayahan, "An Evaluation on Landslides (Example of Rize Province)", Fourteenth National Congress of Soil Mechanics and Foundation Engineering, Süleyman Demirel University, Isparta, 337-346, (2012).

6. S. N. Keskin, and A. Cengizhan, "Comparison of the Traditional Method and Finite Element Method in Basic Settlement Calculations", Journal of Engineering Sciences and Design, vol. 7, no 1, pp. 136-144, 2019. 
7. Ş. Adatepe, A. Gökalp and R. Düzceer, "Performance of Different Braces in a Deep Excavation Application in Istanbul Graywackes", Fourteenth National Congress of Soil Mechanics and Foundation Engineering, Süleyman Demirel University, Isparta, 431-442, (2012).

8. O. Enkhtur, T. D. Nguyen, J. M., Kim and S. R. Kim, "Evaluation of Settlement Influence Factors of Shallow Foundation by Numerical Analyses", KSCE Journal of Civil Engineering, vol. 17, no 1, pp. 85-95, 2013.

9. G. Misir and M. Laman, "Examination of Circular Foundations on Stratified Soils by Tests and Analytical Method", Çukurova University Faculty of Engineering and Architecture Journal, vol. 30, no 19, pp. 249-256, 2015.

10. M. Sunkar and S. Tonbul, "Geomorphology Iluh Stream of River Basin Batman, Istanbul University Faculty of Literature Department of Geography, Journal of Geographical, vol. 24, pp. 38-60, 2013.

11. Y. Eren, M. T. Nalbantçılar, T. Beyaz, S. Dinç, M. Ünal, Ş. Arslan and S. Polat, "Tectonism of Esentepe (Gültepe/Batman) Hole”, Batman University Journal of Life Sciences, vol. 1, no 2, pp. 385-394, 2012.

12. T. Bolgi, "V. Petrol Region Section Measurements Structural Studies between the Field Numbered
AR/TPO/261 and the Field West of Reşan-Dodan", Turkish Petroleum Corporation Research Group, Report No: 162, Ankara, (1961).

13. D. Tuna, "Explanatory Report of Lithostratigraphic Units in Region IV", TPAO Search Group, Archive No. 813, (1973).

14. D. Perinçek, "The Geological Examination of Çelikhan-Sincik-Koçali (Adiyaman) Area", TPAO Search Group, Report No: 1395, (1979).

15. Y. Y1lmaz, "The Tectonics of Amonos Mountains", TPAO Search Group, Report No: 1653, Ankara, (1982).

16. K. Terzaghi and R. B. Peck, Soil Mechanics in Engineering Practice, New York: John Wiley \& Sons, 1948.

17. J. E. Bowles, Foundation Analysis and Design, 4th Edition, Singapore: McGrawHill, 1988.

18. B. H. Fellenius, Basics of Foundation Design Electronic, Vero Beach: Pile Buck International Inc., 2019.

19. R. B. J. Brinkgreve, "Plaxis Finite Element Code for Soil and Rock Analysis, 2d Version 8.2", 2002. 